\title{
Reuse of Residues as Substrate for Production of Eucalyptus (Eucalyptus urograndis) Seedlings
}

\author{
Paola Alfonsa Vieira Lo Monaco ${ }^{1}$ (D) 0000-0001-5498-7451 \\ Gevson Roldi Junior ${ }^{2}$ (D) 0000-0002-5920-8565 \\ Ismail Ramalho Haddade ${ }^{1}$ (D) 0000-0003-0303-8808 \\ Marcelo Rodrigo Krause ${ }^{3}$ (D) 0000-0002-7035-9030 \\ Louise Pinto Guisolfi ${ }^{3}$ (D) 0000-0002-7923-2562 \\ Karoline Matiello Almeida ${ }^{3}$ (D) 0000-0002-4256-0423
}

\begin{abstract}
Studies about crop residue management have become essential due to the possibility of their use in forest seedlings production. This study evaluated the effect of coffee moinha (MO) on substrates composed of vermiculite (VE), coconut fiber (CF) and carbonized rice husk (CRH) in the development of Eucalyptus seedlings. The experiment was conducted in a completely randomized design, with five treatments of increasing proportions of $\mathrm{MO} / \mathrm{dec}$ easing proportions of CRH $(0 / 28,7 / 21,14 / 14,21 / 7$ and 28/0\%) and fixed proportions of VE (36\%) and CF (36\%) in the substrate. At 85 days after planting, the following parameters were assessed: shoot height, stem diameter, root dry mass, shoot dry mass, emergence percentage and Dickson's quality index (DQI). The results showed CRH could be fully substituted by $\mathrm{MO}(28 \%)$ in the substrate composition because the assessed variables presented lower values than the control treatment $(0 \% \mathrm{MO}+28 \% \mathrm{CRH}+36 \% \mathrm{VE}+36 \% \mathrm{CF})$. Moreover, the maximum vegetative development in Eucalyptus seedlings was achieved when CRH was replaced by up to $20 \% \mathrm{MO}$. In this way, MO becomes an alternative as a substrate component for Eucalyptus seedlings production.
\end{abstract}

Keywords: forest seedlings, environmental economics, agricultural residues.

\section{INTRODUCTION AND OBJECTIVES}

Seedlings grown in forest nurseries provide planting stocks for implantation of forest stands, recovery of degraded areas, urban afforestation and parks, among other purposes (Walker et al., 2011). According to Zanetti (2008), Brazil has one of the largest cultivated areas of fast-growing forests, especially Pinus and Eucalyptus species. One of the most important stages in the establishment of tree plantations is the production of quality seedlings, conditioned by adequate seeds and substrates (Silva et al., 2014).

The production of good quality seedlings depends on the germination processes, as well as the formation of the root and shoot systems, which are directly related to the aspects that define the substrate efficiency, such as aeration, drainage, water retention and nutritional content (Caldeira et al., 2008).
The type of potting technique may additionally influence seedling quality and production costs (Kostopoulou et al., 2011). In this context, the conical plastic pot ("cone-tainer") is the most popular for forest seedling production (Wendling \& Dutra, 2010).

In general, no single substrate meets all the conditions necessary to achieve a satisfactory growth of forest seedlings. So a mixture of different substrates is recommended, as they may present undesirable characteristics to the plant, when used alone (Caldeira et al., 2011).

$\mathrm{VE}$ is as an inert mineral of low density and variable structure, composed of tetrahedral silica sheets and iron and magnesium octahedral sheets (Caldeira et al., 2013). Coconut shell fiber has also proven useful in the production of high-quality substrates because of its longevity without deterioration of its characteristics, non-reaction with fertilizer nutrients, physical

\footnotetext{
${ }^{1}$ Instituto Federal de Educação, Ciência e Tecnologia do Espírito Santo (IFES), Santa Teresa, ES, Brasil

${ }^{2}$ Universidade Federal do Espírito Santo (UFES), Alegre, ES, Brasil

${ }^{3}$ Universidade Federal de Viçosa (UFV), Viçosa, MG, Brasil
} 
properties (e.g., porosity), the possibility of sterilization, high primary quality and low cost to the producer (Carrijo et al., 2002). Additionally, $\mathrm{CRH}$ allows the penetration and exchange of air at the base of the roots (Saidelles et al., 2009). When evaluating the attributes of commercial substrates mixed with CRH in different proportions, Klein et al. (2002) verified that this material improved the physical and hydraulic properties of the substrates, providing better porosity. Hence, since $\mathrm{CRH}$ acts predominantly as a physical conditioner of the substrate, it must be used in conjunction with other materials that provide the nutrients for adequate vegetative development of the seedlings.

Thus, organic residues, as alternative substrates for forest seedlings production, have been studied extensively (Caldeira et al., 2013; Da Ros et al., 2015; Delarmelina et al., 2014; Figuerêdo et al., 2014; Silva et al., 2014). Besides possessing physical and chemical attributes that are fundamental to improving the quality of the substrate, the use of organic residues, especially if available in the cultivating area, can minimize the risk of environmental contamination resulting from improper disposal and reduce production costs.

In the mountainous region of Espírito Santo, Brazil, coffee straw stands out as one of the most generated organic residues. Also known as moinha (MO), coffee straw is a byproduct of the coffee drying process composed of plant remains, such as leaves, branches, inflorescences and poorly formed fruits, which, when dried together with the coffee cherries, are burned and released from the dryer (Meneghelli et al., 2016). When chemically characterizing this material, Meneghelli et al. (2016) verified its potential use as a fertilizer, due to high contents of phosphorus, potassium and, especially, nitrogen.

It is believed that $\mathrm{MO}$, combined with VE and CF, can be a promising combination as it provides chemical and physical attributes essential for substrate quality. Also, the MO may be an alternative to rice straw, notably in regions where rice residues are not available in high amounts. In this way, it is necessary to obtain the ideal proportion of each residue that provides quality seedlings and with adequate vegetative development.

Thus, the current work aimed to evaluate the effect of the coffee processing residue (i.e., $\mathrm{MO}$ ) on substrates composed of VE, CF and CRH in the development of Eucalyptus seedlings, and obtain the proportion of these materials in order to achieve the best vegetative development.

\section{MATERIALS AND METHODS}

The experiment was carried out at the Eucalyptus nursery sector of the Fibria Celulose S.A. company, in the Aracruz unit (Espírito Santo, Brazil), for 85 days. The Aracruz unit is in the Atlantic Forest coastal region, with geographical coordinates of $19^{\circ} 49^{\prime} 13^{\prime \prime} \mathrm{S}$ and $40^{\circ} 16^{\prime} 24^{\prime \prime} \mathrm{W}$, and an altitude of $60 \mathrm{~m}$. The climate is "Aw," based on Köppen's classification, with an average annual rainfall of $1.327 \mathrm{~mm}$, and an average annual temperature of $28^{\circ} \mathrm{C}$.

A completely randomized design (CRD) was used, with five treatments and six replicates, with each repetition consisting of 56 plants. In total, eight plants per replicate were evaluated. The treatments consisted of increasing levels of coffee processing residue (MO) in the substrate, mixed with CRH, VE and CF. The control treatment consisted of $\mathrm{CRH}, \mathrm{VE}$ and CF in the same proportions used by Fibria Celulose S.A. The compositions of all treatments are shown in Table 1.

The MO was collected at a coffee processing unit in the municipality of Santa Teresa, ES, Brazil, while the other materials used in the composition of the substrates were donated by Fibria Celulose S.A. The chemical and physicochemical characterization of the residues used in the composition of the substrates for the production of Eucalyptus seedlings was carried out at the Laboratory of Soils and Solid Residues in the Agricultural Engineering Department of the Universidade Federal de Viçosa (Viçosa, Brazil). The physicochemical analysis consisted of the determination of the electrical conductivity, using a bench conductivity meter. The chemical analysis involved measuring of the $\mathrm{pH}$, by means of a benchtop $\mathrm{pH}$ meter, and the quantification of the readily oxidizable organic carbon, total organic carbon, organic matter, total nitrogen, phosphorus and potassium contents, following the method described by Matos (2015). Table 2 presents the chemical and physicochemical attributes (electrical conductivity) of the CF, MO and CRH used in the experiment.

Sprouts from the hybrid clone "Ara 6791" (Eucalyptus urophylla $\times$ Eucalyptus grandis), of approximately $10 \mathrm{~cm}$ in length and three pairs of leaves were obtained from the mini-clonal garden of the Fibria Celulose S.A nursery. After being collected, the sprouts were stored in thermal boxes for a few minutes until transplanted to the growing container. The chosen clone presents fast development and vigorous seedlings, with satisfactory root and shoot formation.

In the sowing sector, where the air humidity was close to $100 \%$, the cuttings were transplanted in trays with 176 cone-tainer single cells (conical tubes made of rigid plastic), with a volumetric capacity of $50 \mathrm{~cm}^{3}$ each, filled with the different substrate mixes (treatments). In all treatments, $12 \mathrm{~g}$ of single superphosphate and $8.5 \mathrm{~g}$ of the nitrogenphosphate-potassium formulation 19-6-10 were added per tray, according to recommendations obtained by surveys conducted by Fibria Celulose S.A. 
Table 1. Composition of substrates for the production of Eucalyptus seedlings (v:v).

\begin{tabular}{cl} 
Control & $\mathbf{0 \%} \mathbf{M O}+\mathbf{2 8} \% \mathbf{C R H}+\mathbf{3 6} \% \mathbf{V E}+\mathbf{3 6} \% \mathbf{C F}$ \\
\hline $\mathrm{T} 1$ & $7 \% \mathrm{MO}+21 \% \mathrm{CRH}+36 \% \mathrm{VE}+36 \% \mathrm{CF}$ \\
$\mathrm{T} 2$ & $14 \% \mathrm{MO}+14 \% \mathrm{CRH}+36 \% \mathrm{VE}+36 \% \mathrm{CF}$ \\
$\mathrm{T} 3$ & $21 \% \mathrm{MO}+7 \% \mathrm{CRH}+36 \% \mathrm{VE}+36 \% \mathrm{CF}$ \\
$\mathrm{T} 4$ & $28 \% \mathrm{MO}+0 \% \mathrm{CRH}+36 \% \mathrm{VE}+36 \% \mathrm{CF}$ \\
\hline
\end{tabular}

MO: moinha; CRH: carbonized rice husk; VE: vermiculite; CF: coconut fiber.

Table 2. Chemical and physicochemical attributes of the substrate materials used in the experiment.

\begin{tabular}{|c|c|c|c|c|c|c|c|c|}
\hline \multirow{2}{*}{ Residue } & EC & \multirow{2}{*}{$\mathrm{pH}$} & ROC & $\mathbf{O C}_{\mathrm{T}}$ & $\mathbf{O M}$ & $\mathbf{N}_{\mathrm{T}}$ & $\mathbf{P}$ & $\mathbf{K}$ \\
\hline & dS $\mathbf{m}^{-1}$ & & \multicolumn{6}{|c|}{ dag $k^{-1}$} \\
\hline $\mathrm{CRH}$ & 1.15 & 5.90 & 31.50 & 40.90 & 70.50 & 0.59 & 0.082 & 0.0329 \\
\hline CF & 0.09 & 7.15 & 57.10 & 74.10 & 127.70 & 0.66 & 0.053 & 0.14 \\
\hline MO & 6.49 & 5.60 & 45.3 & 58.9 & 101.5 & 3.7 & 0.14 & 0.71 \\
\hline
\end{tabular}

EC: electrical conductivity; ROC: readily oxidizable organic carbon; $\mathrm{OC}_{\mathrm{T}}$ : total organic carbon; OM: organic matter; $\mathrm{N}_{\mathrm{T}}$ : total nitrogen; $\mathrm{P}$ : phosphorus; K: potassium; $\mathrm{CRH}$ : carbonized rice husk; $\mathrm{CF}$ : coconut fiber; $\mathrm{MO}$ : moinha; $\mathrm{pH}$ : potential of hydrogen in water.

After planting, the trays were transported to the rooting greenhouse, where they remained for 23 days, under a relative humidity above $90 \%$ and temperature of $20^{\circ} \mathrm{C}$ before they were transported to the growing courtyard, where they remained for 22 days, protected by a shading screen, which allowed a 50\% reduction of solar radiation. Finally, the seedlings were transferred to the open courtyard, where they remained for 40 days.

The hardening fertilization was carried out in the open courtyard. At this hardening stage, the seedling is physiologically prepared for the planting in the first weeks that follow. During the hardening process, up to three fertigation are usually carried out daily, prioritizing formulations with a low nitrogen:potassium ratio since this phase is extremely critical and directly affects the final quality of the seedlings (Alfenas et al., 2009), as well as the potential for better survival and growth on the outplanting site. In this study, the hardening fertilization was carried out three times a day, via foliar spraying, according to internal technical recommendations of Fibria Celulose S.A. The mineral fertilizers used were calcium nitrate, potassium chloride, monoammonium phosphate, magnesium sulfate, boric acid, copper sulfate and zinc sulfate.

At 85 days after planting, in order to evaluate the vegetative development of the Eucalyptus seedlings, the following parameters were assessed: shoot height (SH), stem diameter $(\mathrm{SD})$, root dry mass (RDM), shoot dry mass (SDM), emergence percentage and the Dickson quality index (DQI). A ruler was used to obtain the $\mathrm{SH}$, measuring from the base to the apical shoot that gave rise to the last leaf. The SD was obtained using a precision digital caliper. The SDM was estimated by cutting the seedlings close to the substrate. To obtain the RDM, the roots were carefully washed in running water over a sieve, packed in paper bags, placed in a forced air circulation oven at $65^{\circ} \mathrm{C}$ until constant weight and then weighed in a $0.01 \mathrm{~g}$ electronic precision balance.

The DQI was determined according to Equation 1 (Dickson et al., 1960):

$$
\mathrm{DQI}=\frac{\mathrm{TDM}}{\frac{\mathrm{SH}}{\mathrm{SD}}+\frac{\mathrm{SDM}}{\mathrm{RDM}}}
$$

Where TDM: total dry mass (g); SDM: shoot dry mass (g); RDM: root dry mass (g); SH: shoot height (cm); SD: stem diameter ( $\mathrm{mm})$.

Seedling survival percentage (SP) was assessed by counting the seedlings at 23 days after planting the cuttings. The errors were submitted to tests of normality (Lilliefors), additivity (Tukey) and homoscedasticity (Bartlett), for the validation of their analyses of variance. Those that did not meet the requirements were transformed, according to criteria by Gravina et al. (2004), again being submitted to the same validation tests. For the errors that still did not meet the assumptions, the Kruskal-Wallis non-parametric test was applied to the data, considering the evaluation of the effects of the treatments by scores.

In the case of significant effects $(p<0.05)$, for the comparisons between the treatments related to the moinha level (quantitative treatments), the degrees of freedom of the treatments were adjusted in the regression models by orthogonal polynomials method. The adjusted models were chosen according to the significance of the regression coefficients, the coefficient of determination and the biological phenomenon. All the statistical analyses were performed using SAEG 9.1 software (2007). 


\section{RESULTS AND DISCUSSION}

Table 3 shows the effects of increasing levels of MO in the substrate on the variables SD, SP and DQI in E. urograndis (E. urophylla $\times$ E. grandis) by the non-parametric KruskalWallis test, at $5 \%$ probability.

According to Table 3, all treatments, except for $\mathrm{T} 1$ (7\% MO), had a statistically superior SD to that of the control treatment $(0 \% \mathrm{MO})$. The $\mathrm{MO}$ level of $28 \%$ provided the largest SD $(3.46 \mathrm{~mm})$, but the value was above that considered ideal for E. grandis seedlings, according to the studies of Lopes et al. (2007); and Wendling \& Dutra (2010) that recognize a minimal thickness of 2.0 and $2.5 \mathrm{~mm}$, respectively. Souza et al. (2006) described the SD as fundamental in evaluating the survival potential and growth of forest seedlings. Within the same species, the larger the stem diameter, the better their odds of survival, due to their capacity to form and grow new roots. The results obtained in the treatments with increasing levels of MO in the substrate composition were similar to those found by Silva et al. (2012), which registered SD values ranging from 3.03 to $3.58 \mathrm{~mm}$ in E. urophylla $\times$ E. grandis seedlings, at 90 days post-staking, grown on substrates composed of VE, CRH and CF. However, comparatively lower SD values were published by Caldeira et al. (2013), of between 2.60 and $3.25 \mathrm{~mm}$ in E. grandis seedlings, at 90 days after sowing, grown on substrates with different percentages of sewage sludge and VE; and da Silva et al. (2014), of 1.51 and $1.90 \mathrm{~mm}$ in E. grandis seedlings grown in different types and combinations of organic agroindustrial-urban substrates at 90 days after sowing.

For the SP variable (Table 3), there was no statistical difference at $5 \%$ probability level, indicating that $28 \% \mathrm{MO}$ may be an alternative option to the use of rice straw as a component of the substrate. Rocha et al. (2015) mentioned that this homogeneity and the high survival rates might be reflective of the type of propagation method used in the experiment. In the current study, the clone used has the characteristics of genetic homogeneity of the seedlings and a high percentage of survival.
As highlighted by Vidal et al. (2006), the DQI is a good indicator of seedling quality since the robustness and the balance of the biomass distribution are considered in its calculation. According to this author, the higher the DQI, the better the quality of the seedlings. Here, the highest DQI values (Table 3), 0.211 and 0.212 , were obtained in treatments $\mathrm{T} 1$ (7\% MO) and $\mathrm{T} 2$ (14\% MO), respectively, differing statistically from the control ( $0 \% \mathrm{MO})$. It is believed that the substrate containing $14 \% \mathrm{MO}$ and $14 \% \mathrm{CRH}$ provided the highest DQI, due to the adequate nutrient supply (i.e., $\mathrm{MO}$ ) and ideal porosity (i.e., $\mathrm{CRH}$ ) presented by this combination. With increasing levels of MO in the substrates, the DQI values in the treatments ( 0.199 to 0.212 ) can be considered good results when compared with those obtained by Silva et al. (2012), who also worked with E. urograndis mini cuttings for seedlings production. The DQI obtained by these authors ranged from 0.120 to 0.190 , at 90 days after planting, when evaluating the development and quality of clonal seedlings in nine different substrate compositions produced from VE, CRH and CF. The results achieved in the present work were also superior when compared with other literature data, albeit with other species and using seed propagation. Silva et al. (2014) registered DQI values ranging between 0.032 and 0.056 in E. grandis seedlings, grown on different types and combinations of urban and agroindustrial organic substrates, at 90 days after sowing. Figuerêdo et al. (2014), when studying the effect of different proportions of CRH and substrates on E. globulus seedlings, ascertained DQI values ranging between 0.0042 and 0.015 , at 65 days after sowing. Steffen et al. (2011) analyzed $E$. grandis seedlings at 100 days after germination, and the DQI values ranged from 0.12 to 0.21 , considering different vermicompost ratios in the substrate. It is acknowledged that the DQI can vary depending on the species, seedling management at the nursery, type and proportion of the substrate, container volume and, especially, the age at which the seedling was appraised (Caldeira et al., 2013).

The SH, SDM and RDM of the seedlings, are presented in Figures 1a-c, respectively, as a function of the different percentages of MO in the substrate composition.

Table 3. Effect of increasing levels of moinha on the variables of stem diameter (SD), survival percentage (SP) and Dickson's quality index (DQI) in E. urograndis seedlings, at 85 days after planting.

\begin{tabular}{|c|c|c|c|c|c|c|}
\hline \multirow{2}{*}{ Variable } & \multicolumn{6}{|c|}{ Moinha level in the substrate (\%) } \\
\hline & $\mathbf{0}$ & 7 & 14 & 21 & 28 & $p$-value \\
\hline $\mathrm{SD}(\mathrm{mm})$ & $2.87 \mathrm{c}$ & $3.24 \mathrm{abc}$ & $3.42 \mathrm{ab}$ & $3.41 \mathrm{ab}$ & $3.46 \mathrm{a}$ & 0.0055 \\
\hline SP $(\%)$ & $75 \mathrm{a}$ & $100 \mathrm{a}$ & 85 a & $95 \mathrm{a}$ & 85 a & 0.3724 \\
\hline DQI & $0.121 \mathrm{c}$ & $0.211 \mathrm{ab}$ & $0.212 \mathrm{a}$ & $0.199 \mathrm{abc}$ & $0.209 \mathrm{abc}$ & 0.0107 \\
\hline
\end{tabular}

Means followed by the same letters are equal to each other by the Kruskal-Wallis test, at the 5\% probability level. 
According to Figure 1, all the variables showed a quadratic polynomial behavior, as a function of the different percentages of $\mathrm{MO}$ in the substrate composition. It can be seen in Figure 1a that the $\mathrm{SH}$ increased significantly with the gradual replacement of CRH by up to $19.37 \% \mathrm{MO}$, providing a maximum height of $35.61 \mathrm{~cm}$. Above this MO level (19.37\%), the SH decreased, which may be related to the high salinity presented by this residue, evidenced by the high electrical conductivity (Table 2). This fact may have contributed to the decrease of the osmotic potential in the substrate, negatively affecting seedling growth. As Harter et al. (2014) stated, high salt concentration in the substrate is a stress factor for plants because it reduces the osmotic potential and exposes the protoplasm to ionic action. The water is osmotically retained in the saline solution so that the increased salt proportion makes it decreasingly available to plants.

Even so, the decrease in $\mathrm{SH}$ at MO levels above 19.37\% did not reach the lowest value verified $(25 \mathrm{~cm})$, which was registered in the treatment with $0 \% \mathrm{MO}$. This observation may be associated with the low nutrient content in the $\mathrm{CRH}$ (especially nitrogen) when compared to the MO (Table 2). However, in all treatments, the seedling height was higher than the minimum of $15 \mathrm{~cm}$ recommended by Wendling \& Dutra (2010) for planting.
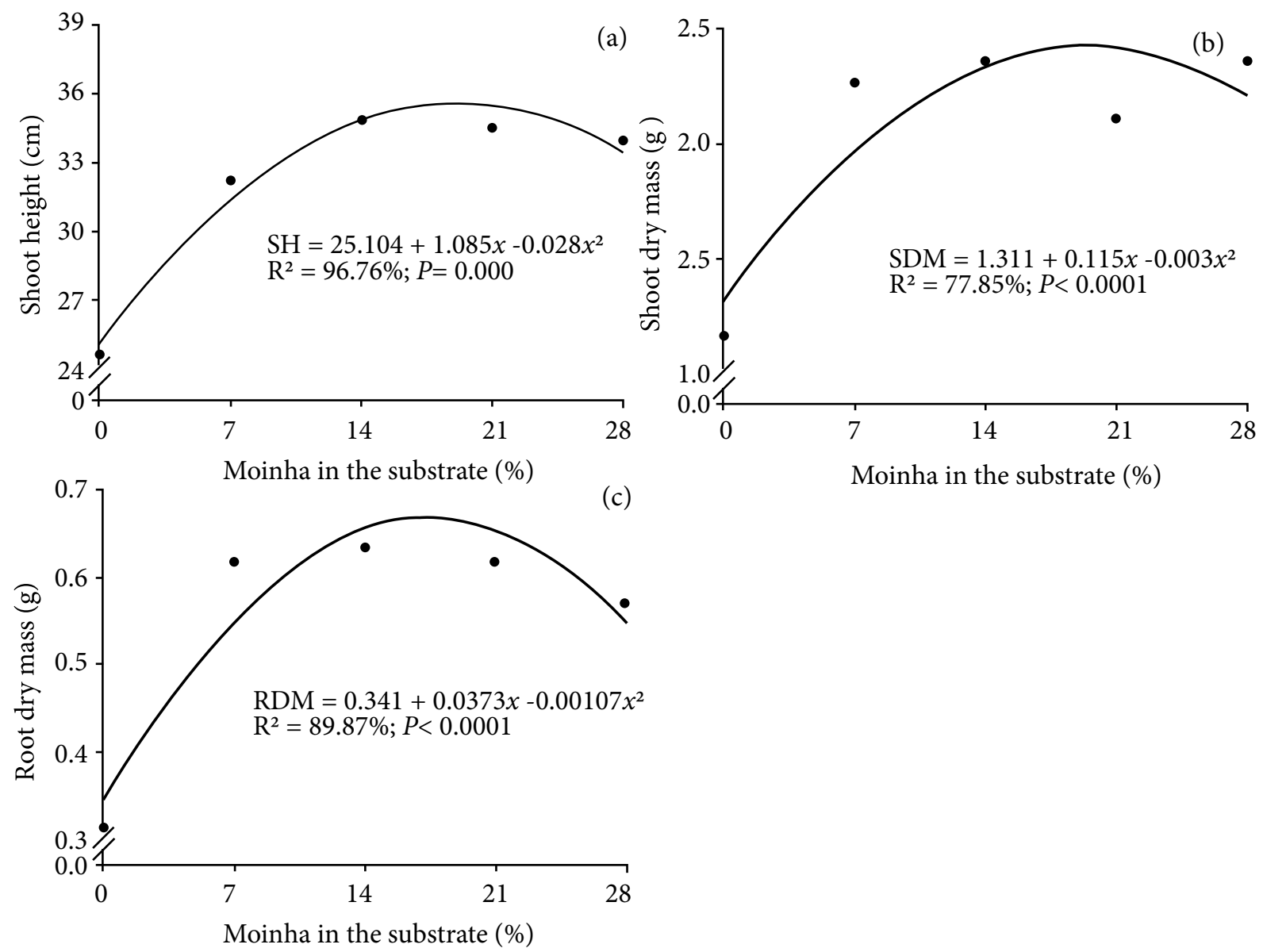

Figure 1. (a) Shoot height, (b) shoot dry mass and (c) root dry mass of Eucalyptus urograndis seedlings as a function of the different percentages of moinha in the substrate composition.

Similarly to the current work, Silva et al. (2012) registered SH values ranging between 27.1 and $37.5 \mathrm{~cm}$, at 90 days after staking, in E. urophylla $\times$ E. grandis seedlings grown in substrates containing VE, CRH and CF. Likewise, de Toledo et al. (2015) determined an $\mathrm{SH}$ of 18.73 to $37.30 \mathrm{~cm}$, in $E$. urograndis seedlings, at 120 days after sowing, grown on substrates composed of paper and cellulose industrial waste. On the contrary, Rocha et al. (2015) recorded SH of between 11.09 and $20.16 \mathrm{~cm}$ in seedlings of the same Eucalyptus species, grown on substrates composed of water treatment sludge.

As seen in Figure 1b, the SDM increased significantly as the MO level increased, up to $19.16 \%$, providing an average 
of $2.41 \mathrm{~g}$. Above this MO level (19.16\%), as verified for the variable $\mathrm{SH}$, a decrease in $\mathrm{SDM}$ values occurred. The lowest SDM value $(1.33 \mathrm{~g})$, provided by the control treatment $(0 \%$ $\mathrm{MO}$ and $28 \% \mathrm{CRH}$ ), could be associated with nitrogen limitation, a fundamental nutrient in the formation of seedlings. A nitrogen deficiency in seedlings is known to hamper development and reduce the accumulation of dry matter (Malavolta, 1980). CRH contains less nitrogen when compared with $\mathrm{MO}$ (Table 2), and this could have contributed to the lower SDM value. The salinity effect in substrates with MO levels above $19.16 \%$, as noted for the $\mathrm{SH}$, may have surpassed the high nutrient availability effect, providing lower SDM values.

The SDM values verified in this study were higher than those given by Silva et al. (2012) of 1.10 and $1.72 \mathrm{~g}$, at 90 days after staking, in E. urophylla $\times$ E. grandis seedlings grown on substrates produced from VE, CRH and CF. Likewise, comparatively lower SDM measurements of 0.99 and $1.82 \mathrm{~g}$ in Eucalyptus seedlings cultivated on substrates composed of VE, CRH and CF have been established by Simões et al. (2012); and de Toledo et al. (2015), who found between 0.88 and $1.52 \mathrm{~g}$ in Eucalyptus seedlings grown on substrates constituted of pulp and paper-making wastes.

It is well recognized that the root system quality is a critical factor for the performance of the seedlings in the field and, hence, is a parameter of paramount importance in the definition of seedling quality (Simões et al., 2012). From Figure $1 \mathrm{c}$, the RDM increased significantly with the gradual replacement of the CRH by up to $17.42 \% \mathrm{MO}$, providing a value of $0.67 \mathrm{~g}$, but decreased at higher MO percentage, as already verified for the other variables. It is noteworthy that all MO levels provided RDM values above $0.55 \mathrm{~g}$, which was consistent with previous researchers. Simões et al. (2012) found RDM values between 0.23 and $0.59 \mathrm{~g}$, similar to those published by de Toledo et al. (2015), with results between 0.47 and $0.78 \mathrm{~g}$; and by da Silva et al. (2012), with values between 0.35 and $0.69 \mathrm{~g}$.

The results obtained in this work show that CRH can be fully substituted by MO (28\%) in the substrate composition since the assessed variables presented lower values when the seedlings were submitted to the control treatment $(0 \% \mathrm{MO}+28 \% \mathrm{CRH}+36 \% \mathrm{VE}+36 \% \mathrm{CF})$. However, maximum Eucalyptus seedlings vegetative development is achieved when replacing the $\mathrm{CRH}$ with up to $20 \% \mathrm{MO}$ in the substrate. As such, MO becomes an alternative substrate component for Eucalyptus seedlings cultivation, in addition to its environmentally harmonic disposal.

Therefore, these positive agronomic results, along with the necessity to offer a suitable destination for agroindustrial wastes and byproducts, demonstrate that organic residues from the coffee drying process (i.e., MO), as a component of substrates, are a feasible alternative for the production of E. urophylla $\times$ E. grandis clonal seedlings.

\section{CONCLUSIONS}

The reuse of coffee drying process residues (i.e., $\mathrm{MO}$ ) in the composition of substrates to produce seedlings of $E$. urophylla $\times E$. grandis is a viable alternative for the final disposal of these wastes.

The MO can be used in the composition of the alternative substrate in a proportion of up to $28 \%$, in substitution of the $\mathrm{CRH}$, to produce Eucalyptus seedlings.

The use of up to $20 \% \mathrm{MO}$ in the composition of the substrate in substitution of the $\mathrm{CRH}$ provides better quality seedlings of E. urophylla $\times$ E. grandis.

\section{ACKNOWLEDGEMENTS}

The authors thank the Conselho Nacional de Desenvolvimento Científico e Tecnológico (CNPq) for the scholarship granted, the company Fibria for the partnership to carry out the experiment and Postgraduate Deanship Scientific Dissemination Program (PRODIF) for assistance in publication this manuscript.

\section{SUBMISSION STATUS}

Received: 23 Mar. 2018

Accepted: 9 Apr. 2019

Associate editor: Natália Corniani

(D) 0000-0001-7342-5171

\section{CORRESPONDENCE TO}

\section{Marcelo Rodrigo Krause}

Universidade Federal de Viçosa (UFV), Av. Peter Henry Rolfs, s/n, Campus Universitário, Viçosa, MG, Brasil

e-mail: agro.krause@gmail.com

\section{REFERENCES}

Alfenas AC, Zauza AAV, Mafia RG, Assis TF. Clonagem e doenças do eucalipto. 2nd ed. Viçosa: UFV; 2009.

Caldeira MV, Delarmelina WM, Peroni L, Gonçalves EO, Silva AG. Lodo de esgoto e vermiculita na produção de mudas de eucalipto. Pesquisa Agropecuária Tropical 2013; 43(2): 155-163. 10.1590/ S1983-40632013000200002

Caldeira MV, Rosa GN, Fenilli TAB, Harbs RMP. Composto orgânico na produção de mudas de aroeira-vermelha. Scientia Agraria 2008; 9(1): 27-33. 10.5380/rsa.v9i1.9898

Caldeira MV, Wendling I, Penchel RM, Gonçalves EO, Kratz D, Trazzi PA. Principais tipos e componentes de substratos para produção de mudas de espécies florestais. In: Caldeira MVW, Garcia GO, Gonçalves EO, Arantes MDC, Fiedler NC. Contexto e perspectivas da área florestal no Brasil. Visconde do Rio Branco: Suprema; 2011. p. 51-100. 
Carrijo OA, Liz RS, Makishima N. Fibra da casca do coco verde como substrato agrícola. Horticultura Brasileira 2002; 20(4): 533-535. 10.1590/S0102-05362002000400003

Da Ros CO, Rex FE, Ribeiro IR, Kafer PS, Rodrigues AC, Silva RF, Somavilla L. Uso de substrato compostado na produção de mudas de Eucalyptus dunnii e Cordia trichotoma. Floresta e Ambiente 2015; 22(4): 549-558. 10.1590/2179-8087.115714

Delarmelina WM, Caldeira MVW, Faria JCT, Gonçalves EO, Rocha RLF. Diferentes substratos para a produção de Sesbania virgata. Floresta e Ambiente 2014; 21(2): 224-233. 10.4322/floram.2014.027

Dickson A, Leaf AL, Hosner JF. Quality appraisal of white spruce and white pine seedling stock in nurseries. Forestry Chronicle 1960; 36(1): 10-13. 10.5558/tfc36010-1

Figuerêdo KS, Silva RR, Dias MAR, Freitas GA, Ribeiro MMC, Melo AV. Adição de casca de arroz carbonizada em diferentes substratos para produção de mudas de Eucalyptus globulus. Journal Biotechnology and Biodiversity 2014; 5(1): 71-78. 10.20873/jbb.uft.cemaf.v5n1.figueredo

Gravina GA, Cecon PR, Martins Filho S, Sediyama CS. Transformação de dados nas estimativas de parâmetros genéticos de resistência dos cultivares de soja Uberaba e Bossier à Cercospora sojina Hara. Ceres 2004; 51(294): 215-225.

Harter LSH, Harter FS, Deuner C, Meneghello GE, Villela FA. Salinidade e desempenho fisiológico de sementes e plântulas de mogango. Horticultura Brasileira 2014; 32(1): 80-85. 10.1590/S010205362014000100013

Klein VA, Camara RK, Simon MA, Dias ST. Casca de arroz carbonizada como condicionador de substrato. In: Furlani AMC. Caracterização, manejo e qualidade de substrato para produção de plantas. Campinas: Instituto Agronômico; 2002.

Kostopoulou P, Radoglou K, Dini-Papanastasi O, Adamidou C. Effect of mini-plug container depth on root and shoot growth of four forest tree species during early developmental stages. Turkish Journal of Agriculture and Forestry 2011; 35(4): 379-390. 10.3906/tar-1104-11

Lopes JLW, Guerrini IA, Saad JCC. Qualidade de mudas de eucalipto produzidas sob diferentes lâminas de irrigação e dois tipos de substrato. Revista Árvore 2007; 31(5): 835-843. 10.1590/S010067622007000500007

Matos AT. Manual de análise de resíduos sólidos e águas residuárias. Viçosa: UFV; 2015.

Malavolta E. Elementos de nutrição mineral de plantas. São Paulo: Agronômica Ceres; 1980.

Meneghelli CM, Monaco PAV, Haddade IR, Meneghelli LAM, Krause MR. Resíduo da secagem dos grãos de café como substrato alternativo em mudas de café conilon. Coffee Science 2016; 11(3): 330-335.

Rocha DN, Souza AE, Queiroz LM, Pontes CA. Utilização do lodo da estação de tratamento de água na produção de mudas de eucalipto.
Revista Agrogeoambiental 2015; 17(3): 11-20. 10.18406/2316$1817 \mathrm{v} 7 \mathrm{n} 32015617$

SAEG: Sistema de Análises Estatísticas (versão 9.1) [Internet]. Viçosa: Fundação Arthur Bernardes; 2007 [cited 2020 Mar. 16]. Available from: https://bit.ly/2TU1BKT.

Saidelles FLF, Caldeira MVW, Schirmer WN, Sperandio HV. Casca de arroz carbonizada como substrato para produção de mudas de tamboril-da-mata e garapeira. Semina: Ciências Agrárias 2009; 30(1): 1173-1186. 10.5433/1679-0359.2009v30n4Sup1p1173

Silva RBG, Simões D, Silva MR. Qualidade de mudas clonais de Eucalyptus urophylla $\times$ E. grandis em função do substrato. Revista Brasileira de Engenharia Agrícola e Ambiental 2012; 16(3): 297-302. 10.1590/S1415-43662012000300010

Silva RF, Eitelwein MT, Cherubin MR, Fabbris C, Weirich S, Pinheiro RR. Produção de mudas de Eucalyptus grandis em substratos orgânicos alternativos. Ciência Florestal 2014; 24(3): 609-619. $10.5902 / 1980509815745$

Simões D, Silva RBG, Silva MR. Composição do substrato sobre o desenvolvimento, qualidade e custo de produção de mudas de Eucalyptus grandis Hill ex Maiden $\times$ Eucalyptus urophylla S. T. Blake. Ciência Florestal 2012; 22(1): 91-100. 10.5902/198050985082

Souza CAM, Oliveira RB, Martins Filho S, Lima JSS. Crescimento em campo de espécies florestais em diferentes condições de adubação. Ciência Florestal 2006; 16(3): 243-249. 10.5902/198050981905

Steffen GPK, Antoniolli ZI, Steffen RB, Schiedeck G. Utilização de vermicomposto como substrato na produção de mudas de Eucalyptus grandis e Corymbia citriodora. Pesquisa Florestal Brasileira 2011; 31(66): 75-82. 10.4336/2011.pfb.31.66.75

Toledo FHSF, Venturin N, Carlos L, Dias BAS, Venturin RP, Macedo RLG. Composto de resíduos da fabricação de papel e celulose na produção de mudas de eucalipto. Revista Brasileira de Engenharia Agrícola e Ambiental 2015; 19(7): 711-716. 10.1590/1807-1929/ agriambi.v19n7p711-716

Vidal LHI, Souza JRP, Fonseca EP, Bordin I. Qualidade de mudas de guaco produzidas por estaquia em casca de arroz carbonizada com vermicomposto. Horticultura Brasileira 2006; 24(1): 26-30. 10.1590/S0102-05362006000100006

Walker C, Araújo MM, Maciel CG, Marcuzzo SB. Viveiro florestal: evolução tecnológica e legalização. Revista Verde de Agroecologia e Desenvolvimento Sustentável 2011; 6(5): 8-14.

Wendling I, Dutra LF. Produção de mudas de eucalipto por sementes. In: Wendling I, Dutra LF. Produção de mudas de eucalipto. Colombo: Embrapa Florestas; 2010. p. 13-47.

Zanetti R. Manejo de pragas de viveiros florestais. In: Davide AC, Silva EAA. Produção de sementes e mudas de espécies florestais. Lavras: UFLA; 2008. p. 125-139. 